\title{
Efficiency of Production Factors and Financial Performance of Agricultural Enterprises
}

\author{
M. Novotná, T. Volek \\ Faculty of Economics, University of South Bohemia, Czech Republic
}

\begin{abstract}
Anotace
Článek se zabývá rozborem vztahů mezi efektivností využivání výrobních faktorů v zemědělských podnicích a jejich finanční výkonností. Hlavním cílem článku je vymezit společné ekonomické rysy u zemědělských podniků, kterým dlouhodobě roste produktivita práce a současně dlouhodobě zvyšují hodnotu dlouhodobého majetku (investují). Analýza byla zaměřena na 1098 zemědělských podniků rozdělných dle metodiky Evropské komise na mikro, malé a střední. Provedená analýza ukázala, že nadprůměrné zemědělské podniky (s vysokým růstem produktivity práce a dlouhodobého majetku) bez ohledu na velikostní skupinu dosahují vyšší rentabilitu, mají vyšší zadluženost a nižší pohotovou likviditu. Z hlediska analýzy za jednotlivé velikostní kategorie podniků lze vyvodit, že u menších podniků jsou větší rozdíly u nadprůměrných podniků ve srovnání s celkem.
\end{abstract}

\section{Klíčová slova}

Produktivita práce, dlouhodobý majetek, zemědělství, podniky.

\begin{abstract}
This article deals with the relationship between efficiency of use of the production factors in agricultural enterprises in Czech Republic and their financial performance. The aim of the article is to define common economic features of agricultural enterprises which labour productivity has been growing for a long time and, at the same time; they have been increasing value of their fixed assets (investing). The analysis was focused on 1098 agricultural enterprises classified according to the European Commission as micro, small and medium enterprises. The analysis showed that above-average agricultural enterprises (high growth of labour productivity and fixed assets), regardless of their size, have higher profitability indicators, higher indebtedness and lower quick ratio. Summarizing the results of the analysis of individual size classes, it can be said that the smaller size class, the bigger difference.
\end{abstract}

\section{Keywords:}

Labour productivity, fixed assets, agriculture, enterprises.

Novotná, M. and Volek, T. (2015) "Efficiency of Production Factors and Financial Performance of Agricultural Enterprises", AGRIS on-line Papers in Economics and Informatics, Vol. 7, No. 4, pp. 91 - 99, ISSN 1804-1930.

\section{Introduction}

Labour productivity is the basic indicator showing use of human capital in the enterprise. Labour productivity is influenced by many factors, one of them being enterprise's increase in investment activity. High enterprise investment activity is reflected, primarily, by increasing fixed assets. In economic reality, enterprises with different investment activity dynamics and also labour productivity can be found. The question is whether the enterprises achieving the best results in this area have any common features in performance characteristics and, if so, which. The objective of the article is to define common economic features of agricultural enterprises which labour productivity has been growing for a long time and, at the same time, they have been increasing value of their fixed assets (investing).

The basis for measuring economics efficiency and productivity in agriculture and others branches 
is production function. The neoclassical production function takes the form $\mathrm{Y}(\mathrm{t})=\mathrm{F}[\mathrm{K}(\mathrm{t}), \mathrm{L}(\mathrm{t})$, $\mathrm{T}(\mathrm{t})$ ] where $\mathrm{Y}(\mathrm{t})$ is the flow of output produced at time t. Capital, K (t) represents the durable physical inputs. The second input to the production function is labour, $\mathrm{L}(\mathrm{t})$ and it represents the inputs associated with the human body. The third input is the level of knowledge or technology, T ( $\mathrm{t}$ ) (Barro, Sala-i-Martin, 2004). Productivity is called the ratio output and input (Coelli et al., 2005).

The productivity of agricultural enterprises we can measure by indicators of productivity. The most used indicator is labour productivity. Indicator of labour productivity shows the efficiency of utilization labour in enterprises. Labour productivity can be generally defined as volume of output for one unit of input. Labour productivity we can write value added per labour (Oosterhaven, Broersma, 2007). We have other types of productivity as capital productivity or total factor productivity. The capital productivity shows how productively capital is used to generate value added. Total factor productivity measure technological change. Total factor productivity determines labour productivity, not only directly, but also indirectly by determining capital per worker (Prescott, Lawrence, 1998). Labour productivity for agricultural can be characterized by an equation where there is volume of production in numerator and volume of labour in denominator (Brčák, 2009). More appropriate indicators are total costs per labour costs. For definition of enterprise's or region's position, graphical illustration of the relationship can be used, for instance, between increase in labour productivity and employment rate (Cuadrado-Roura et al, 1999) or between labour productivity growth and fixed assets growth. Labour productivity in agriculture is influenced by many factors. Ball et al. (2014) told that labour productivity growth was inversely related to specialization. Highly specialized farms were among the productivity leaders but they exhibited slower rates of productivity growth than did less specialized producers. On the other hand, Van den Ban (2011) claims that changing the farming system to increase labour productivity is risky. Farmers have to decide themselves which risks they are able and willing to take. Some farmers have taken managerial decisions, which increased their income a lot, but others regret that they have taken a decision which caused big losses (Van den Ban 2011). Other perspective was offered by Lososová, Zdeněk (2014), stating that farming constitutes a significant factor influencing labour productivity. The enterprises in LFA have higher productivity than those outside of LFA.

The important driver of productivity growth in agriculture is also scientific progress. The reason for the agricultural sector productivity growth in relation to the number of economically active persons in agriculture is the growth of investments especially into machinery and new technologies (in the period 1993-2011) (Svatoš et al., 2014). Similar conclusion was reached by Čechura (2012), stating that the most important factors which determine both technical efficiency and TFP are those connected with institutional and economic changes, in particular a dramatic increase in the imports of meat and increasing. Other authors assume that strong capital flows into the agricultural sector encourage agricultural production levels, (Žídková, et al., 2011).

Factor intensity and efficiency change are found to be sources of labour productivity convergence while technical change is found to be a source of divergence. Policies that encourage investment in capital goods may help to mitigate disparities in labour productivity across the farm sector (Mugera et al., 2012). According to another opinion, hired labour quality is claimed to be an important factor influencing labour productivity. Hired labor are used as the labor inputs. The quality of hired labor is quite different across farms. These labor quality differences are reflected in different wage rates (Kazukauskas et al., 2014)

\section{Materials and methods}

The article is aimed at evaluation of agricultural enterprises in Czech Republic with respect to efficiency of the labour production factor in connection with change in fixed assets. Primarily, it was analyzed whether agricultural enterprises that make investments and increase fixed assets value also increase labour productivity. Another question the research should respond to was whether labour productivity growth is also associated with rising financial performance of the enterprise. The analysis was aimed at characterizing the successful class of enterprises and providing specification of common features of these enterprises, based on defined criteria and also considering size classes. The above-average (IA) enterprise was considered the one achieving average increase in its fixed assets and labour productivity more than 1.0 in the reference period.

We used, for the following investigation, the company database called ALBERTINA, which contains accounting data of 1098 farms 
(agricultural enterprises) with at least one employee. The observed company data were from the 6 year period (2007-2012) and the set of the 1098 companies was for the whole observation period invariable. The farms were assigned, in every year, according to their size into four categories defined by the European Commission (European Commission Directive (ES) No. 800/2008): micro, small, medium and large sized enterprises. Paper is focused on the analyses of micro, small and medium sized enterprises. Micro enterprises have fewer than 10 employees and their turnover or balance sheet total does not exceed 2 million Euros. Small firms have less than 50 employees and their turnover or balance sheet total does not exceed 10 Million Euros. The Commission further regards an enterprise with fewer than 250 employees, a turnover not exceeding 50 million Euro or a balance sheet total not exceeding 42 Million Euros as a medium-sized enterprise.

Totally, the analysis included 1098 enterprises in the ALBERTINA database. These enterprises had not been changed throughout the period of reference $(2007-2012)$ and their activity belongs to section A according to classification made by NACE-CZ. Core data were sourced from financial records (balance sheet, profit and loss account). Performance of agricultural enterprises is largely influenced by external conditions (influence of climatic conditions, price development). At first, the authors attempted to eliminate the influence of price on the indicators used for classification of the enterprises, particularly revenue indictor which was converted using agricultural producer price index; personnel cost index was deflated using consumer index prices. Gross fixed capital formation (GFCF) in sector Agriculture, Forestry and Fishing was selected from the database of annual national accounts for adjustment of prices in the fixed assets indicator. Aggregate value in current prices and prices of previous period prices was used for conversion. At first, year- to-year price indices, i.e. GFCF share in current prices as well as GFCF in prices of previous period in the same year were established, which means use of aggregated price indices. For instance, in 2007.

$$
I p_{2007 / 2006}=\frac{G F C F_{2007(2007)}}{G F C F_{2007(2006)}}=\frac{\sum p_{2007} q_{2007}}{\sum p_{2006} q_{2007}}
$$

Where

$\mathrm{GFCF}_{\text {2007(2007) }}$ - Gross fixed capital formation in section A in $2007\left(q_{2007}\right)$ in current prices, i.e. prices of $2007\left(p_{2007}\right)$,

$G F C F_{2007(2006)}$ - Gross fixed capital formation in section $\mathrm{A}$ in $2007\left(q_{2007}\right)$ in prices of previous period, i.e. $20067\left(p_{2006}\right)$.

Resulting price indices were gradually converted to price indices using the relationship between chain and basic indices, with the basis being 2007 (Table 1).

These indices were used for conversion of the indicators above, hence, the values of all indicators are given in prices of 2007.

The enterprises were classified by their size (i.e. micro, small and medium) in accordance with categorization of the European Commission (Commission Regulation No 800/2008). Large enterprises were not included.

Average growth rate of Fixed assets FA indicator (sum of intangible assets and tangible assets) and labour productivity LP (share of revenues and personnel costs) in the relevant interval were used as the criterion of assessment. Based on development of these indicators, four quadrants were defined:

\begin{tabular}{|l|l|}
\hline Quadrant I & I FA $>1$ and at the same time I LP $>1$ \\
\hline Quadrant II & I FA $>1$ and at the same time I LP $<1$ \\
\hline Quadrant III & I FA $<1$ and at the same time I LP $<1$ \\
\hline Quadrant IV & I FA $<1$ and at the same time I LP $>1$ \\
\hline
\end{tabular}

In following, the authors focused on Quadrant I,

\begin{tabular}{|l|c|c|c|c|c|c|}
\hline & 2007 & 2008 & 2009 & 2010 & 2011 & 2012 \\
\hline $\begin{array}{l}\text { GFCF* - A Agriculture, } \\
\text { forestry and fishing }\end{array}$ & 1.0000 & 0.9924 & 0.9766 & 0.9891 & 0.9889 & 1.0035 \\
\hline $\begin{array}{l}\text { Agricultural manufacturer } \\
\text { prices }\end{array}$ & 1.0000 & 1.0881 & 0.8180 & 0.8620 & 1.0262 & 1.0686 \\
\hline $\begin{array}{l}\text { Consumer prices of goods } \\
\text { and services (total) }\end{array}$ & 1.0000 & 1.0636 & 1.0750 & 1.0901 & 1.1110 & 1.1480 \\
\hline
\end{tabular}

* Gross fixed capital formation

Source: Own calculations based on the data Czech Statistical Office.

Table 1: Price indices $(100 \%=$ year 2007) of selected indicators. 
and particularly the enterprises which performance was above average (Quadrant I- A). Another performance indicators were then investigated in this class of enterprise by their size, namely: Return on Assets - ROA (EBIT (Earning before Interest and Taxes)/ Assets); Return on Equity - ROE (Earning after Taxes /Equity); Debt ratio (Total Debt/Assets); Quick Asset Ratio ((Current Assets - Inventories)/ (Current Liabilities+ShortTerm Bank Loans)); Personnel costs / Total costs; Added Value/Revenues; Other Operating Revenues/ Total Revenues.

\section{Results and discussion}

At first, agricultural enterprises were divided into four quadrants in compliance with selected criteria (with elimination of price influences, see Methodology), considering also the size of the enterprises (Table 2).

Table 2 shows that distribution of agricultural enterprises by their size is comparatively homogenous. The quantity of enterprises categorized "smallee and "medium" is roughly the same, with the minimum number of "micro"e enterprises. It is obvious that the largest part of enterprises in all size classes belong to Quadrant I, a fact indicating positive trend of monitored values.

In 2007-2012, fixed assets value has been increasing and, at the same time, labour productivity has been growing in approximately $69 \%$ of medium enterprises, $55 \%$ of small enterprises and $43 \%$ of micro enterprises. To a certain extent, this growth of productivity could also have been influenced by falling numbers of the persons working in agriculture (general trend in this sector), which could result in lower personnel costs and, hence, growth of labour productivity. For the purpose of a more detailed analysis, the enterprises which labour productivity rates and fixed asset values were above average (Quadrant I - A) were also excluded. In small and medium enterprise sector, these enterprises constituted approximately one third of units in Quadrant I and approximately one half in micro. Quadrant II is also significantly represented, where fixed assets value increased, however, reduction of labour productivity could be seen at the same time. Obviously, the investments not increasing efficiency of the labour production factor (approx. one fifth of enterprises in all size classes) prevailed. Quadrant IV showing reduction of fixed assets and, at the same time, growth of labour productivity has comparatively strong presence, particularly in micro $(24.9 \%)$ and small (15.2\%) enterprises. This situation applies to medium enterprises only to a limited extent. These facts suggest that the "smaller" the enterprise, the more difficult renewal of its fixed assets (and perhaps also more demanding, in financial terms) and it can also be concluded that outsourcing of some works is more frequent in these enterprises. In enterprise's accounting system, outsourcing is reflected by higher share of services, as can be seen in Table 3 with the highest proportion of services in total costs in the enterprises classified in Quadrant IV. Also, it is highly probable that the division into quadrants was largely influenced by the structure of production. The enterprises focusing predominantly on growing of crops will receive more subsidies, thus increasing their yields and, hence, their labour productivity. Table 4 also shows that the enterprises in Quadrant have the highest shares of Other operating revenues in Total revenues. The smallest presence of enterprises is in Quadrant III (the largest part is constituted by micro enterprises, i. e. $12.7 \%$, see Table 3). These enterprises are characterized by reduction of fixed assets and, at the same time, decrease in labour productivity. Supplementary indicators (Table 3) show their minimum share in total yields (approximately 13\%), at the same time, their minimum share of services and personnel costs in total costs.

The focus was on Quadrant I, and particularly

\begin{tabular}{|l|c|c|c|c|c|c|}
\hline \multirow{2}{*}{} & \multicolumn{2}{|c|}{ Micro } & \multicolumn{2}{c|}{ Small } & \multicolumn{2}{c|}{ Medium } \\
\cline { 2 - 7 } & absolute & relative & absolute & relative & absolute & relative \\
\hline Quadrant I & 78 & 43.1 & 250 & 55.1 & 314 & 69.3 \\
\hline Quadrant II & 35 & 19.3 & 113 & 24.9 & 93 & 20.5 \\
\hline Quadrant III & 23 & 12.7 & 22 & 4.8 & 22 & 4.9 \\
\hline Quadrant IV & 45 & 24.9 & 69 & 15.2 & 24 & 5.3 \\
\hline Quadrant I - A & 44 & 24.3 & 98 & 21.6 & 98 & 21.6 \\
\hline Total & 181 & 100.0 & 454 & 100.0 & 453 & 100.0 \\
\hline
\end{tabular}

Source: Own calculations based on the data company database Albertina.

Table 2: Absolute and relative numbers of enterprises in individual quadrants. 


\begin{tabular}{|l|c|c|c|}
\hline & $\begin{array}{c}\text { Personnel cost/Total cost in } \\
\text { CZK }\end{array}$ & Services / total cost in CZK & $\begin{array}{c}\text { Other operating revenues/total } \\
\text { revenues in CZK }\end{array}$ \\
\hline Quadrant I & 0.1989 & 0.1473 & 0.1561 \\
\hline Quadrant II & 0.1928 & 0.1425 & 0.1462 \\
\hline Quadrant III & 0.1875 & 0.1353 & 0.1342 \\
\hline Quadrant IV & 0.1950 & 0.2017 & 0.1733 \\
\hline
\end{tabular}

Source: Own calculations based on the data company database Albertina.

Table 3: Results of quadrants.

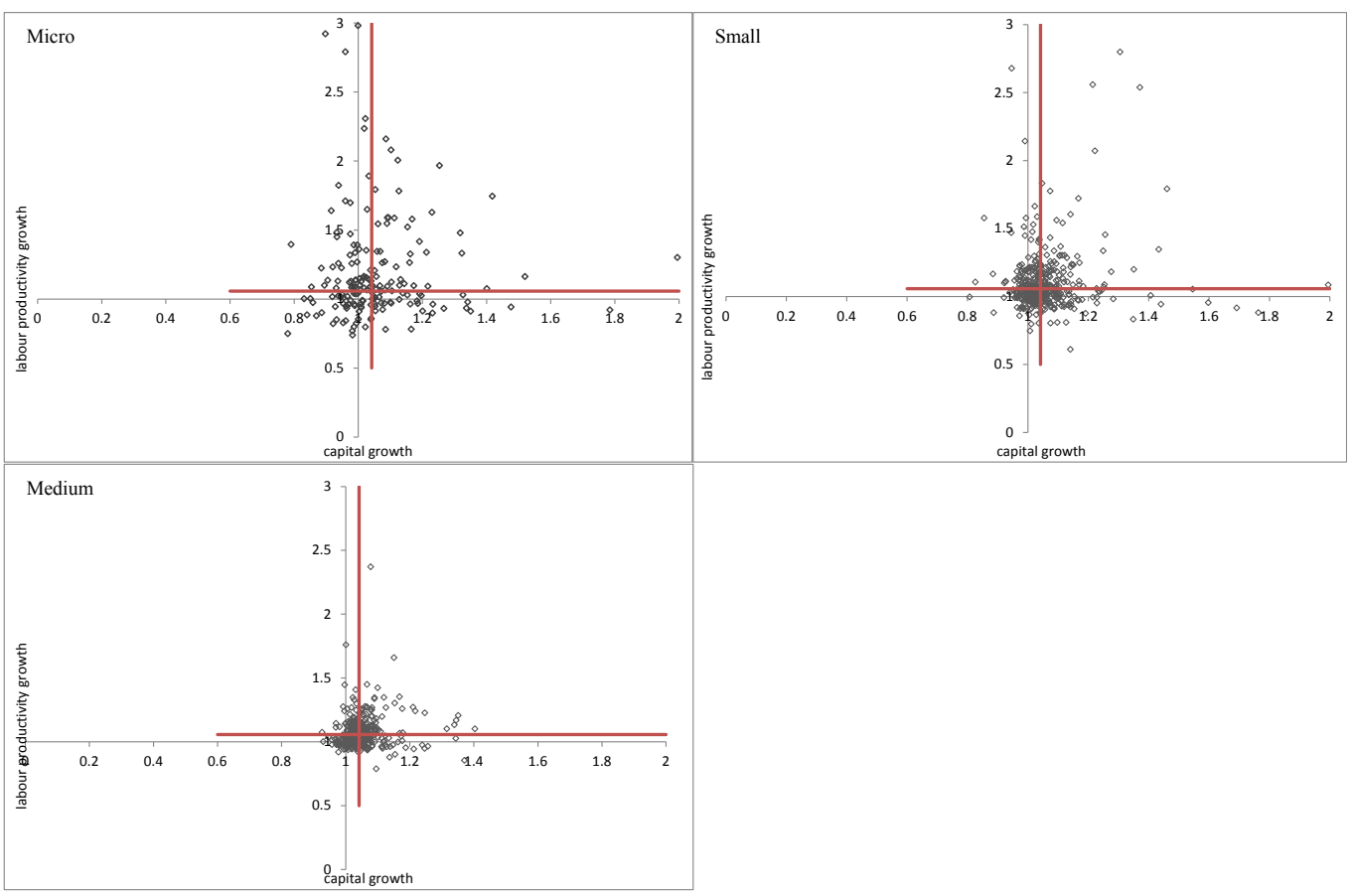

Source: Own calculations based on the data company database Albertina.

Graph 1: Enterprises distribution by their size.

the enterprises which increase in fixed assets and labour productivity was higher than average growth rate of these indicators in the relevant period. The evaluation was made in each size class. The results in individual classes are shown in graphs (graph 1), average value in each class is highlighted with the red line. All enterprises above this line are considered above average.

Varying distribution of enterprises by their size is obvious in all graphs. Whereas structure of micro enterprises is rather scattered (situation of these enterprises is different as far as the criteria are concerned), that of small and, particularly, medium enterprises is comparatively compact and clustered. This suggests that situation of larger enterprises is more stabilized, as far as selected criteria are concerned.

The enterprises in Quadrant I were analysed in a similar manner, i.e. above-average enterprises (IA), in which additional ratio-based indicators were identified in order to discover links between increasing efficiency of enterprise's labour production factor and its financial performance. The aim was to investigate characteristics of this class of enterprises in other areas as well as distinct features of successful enterprises in individual size classes.

As illustrated in table 4 showing selected indicators of micro enterprises, the indicators of profitability (ROE, ROA) assume significantly higher values in above-average enterprises, i.e. those with above-average investment activity and efficiency of the labour production factor. ROE values are twice as high, on average. As far as indebtedness is concerned, above-average enterprises (in terms of the criteria as specified hereinabove) have higher leverage indicator. Also, both enterprise classes (i.e. total and IA) are characterized by decreasing indebtedness in $2007-2012$, ranging $50-60 \%$ in the last relevant 


\begin{tabular}{|l|c|c|c|c|c|c|c|c|}
\hline Ratio & & $\mathbf{2 0 0 7}$ & $\mathbf{2 0 0 8}$ & $\mathbf{2 0 0 9}$ & $\mathbf{2 0 1 0}$ & $\mathbf{2 0 1 1}$ & $\mathbf{2 0 1 2}$ & Average \\
\hline \multirow{2}{*}{ ROA in \% } & IA & 12.97 & 12.13 & 7.1 & 6.47 & 8.89 & 8.6 & 9.06 \\
\cline { 2 - 9 } & Total & 8.8 & 7.7 & 3.18 & 4.21 & 6.38 & 5.65 & 5.66 \\
\hline \multirow{2}{*}{ ROE in \% } & IA & 35.56 & 26.91 & 13.1 & 10.71 & 16.02 & 15.23 & 17.89 \\
\cline { 2 - 9 } & Total & 16.97 & 13.08 & 3.18 & 5.4 & 9.46 & 8.52 & 8.21 \\
\hline \multirow{2}{*}{ Debt ratio v \% } & IA & 70.85 & 62.46 & 62.52 & 59.1 & 57.12 & 58.33 & 61.57 \\
\cline { 2 - 9 } & Total & 60.92 & 57.96 & 56.54 & 54.14 & 52.91 & 54.76 & 56.14 \\
\hline \multirow{2}{*}{ Quick Asset ratio } & IA & 0.817 & 0.859 & 0.725 & 0.699 & 0.647 & 0.823 & 0.758 \\
\cline { 2 - 9 } & Total & 0.947 & 0.995 & 0.941 & 0.921 & 0.911 & 0.877 & 0.931 \\
\hline \multirow{3}{*}{ aalue added/Total revenues } & IA & 0.081 & 0.077 & 0.022 & 0.031 & 0.084 & 0.093 & 0.057 \\
\cline { 2 - 9 } & Total & 0.083 & 0.074 & 0.025 & 0.05 & 0.093 & 0.086 & 0.063 \\
\hline \multirow{2}{*}{ Other operating revenues/ Total revenues } & IA & 0.271 & 0.279 & 0.305 & 0.293 & 0.281 & 0.279 & 0.284 \\
\cline { 2 - 9 } & Total & 0.2 & 0.211 & 0.244 & 0.232 & 0.207 & 0.203 & 0.216 \\
\hline \multirow{2}{*}{ Personnel cost / Total cost } & IA & 0.169 & 0.157 & 0.154 & 0.145 & 0.129 & 0.12 & 0.145 \\
\cline { 2 - 8 } & Total & 0.129 & 0.131 & 0.145 & 0.149 & 0.139 & 0.136 & 0.138 \\
\hline
\end{tabular}

Source: Own calculations based on the data company database Albertina.

Table 4: Selected ratio-based indicators in 2007-2012 - micro enterprises.

\begin{tabular}{|l|c|c|c|c|c|c|c|c|}
\hline Ratio & & $\mathbf{2 0 0 7}$ & $\mathbf{2 0 0 8}$ & $\mathbf{2 0 0 9}$ & $\mathbf{2 0 1 0}$ & $\mathbf{2 0 1 1}$ & $\mathbf{2 0 1 2}$ & Average \\
\hline \multirow{2}{*}{ ROA in \% } & IA & 9.10 & 5.58 & 4.64 & 7.19 & 8.62 & 9.04 & 7.13 \\
\cline { 2 - 9 } & Total & 8.28 & 5.14 & 1.85 & 4.99 & 7.25 & 7.03 & 5.21 \\
\hline \multirow{2}{*}{ ROE in \% } & IA & 14.86 & 7.69 & 5.88 & 10.10 & 11.58 & 12.50 & 9.97 \\
\cline { 2 - 9 } & Total & 12.94 & 6.49 & 0.70 & 6.02 & 9.16 & 8.71 & 5.52 \\
\hline \multirow{2}{*}{ Debt ratio v \% } & IA & 48.72 & 52.94 & 52.55 & 49.89 & 49.62 & 49.08 & 50.44 \\
\cline { 2 - 9 } & Total & 47.46 & 48.86 & 47.35 & 44.13 & 42.59 & 42.13 & 45.35 \\
\hline \multirow{2}{*}{ Quick Asset ratio } & IA & 1.209 & 0.979 & 1.039 & 1.017 & 0.964 & 0.939 & 1.021 \\
\cline { 2 - 9 } & Total & 1.235 & 1.030 & 1.100 & 1.167 & 1.220 & 1.193 & 1.155 \\
\hline \multirow{3}{*}{ aalue added/Total revenues } & IA & 0.198 & 0.166 & 0.100 & 0.145 & 0.167 & 0.172 & 0.154 \\
\cline { 2 - 9 } & Total & 0.191 & 0.159 & 0.098 & 0.150 & 0.179 & 0.175 & 0.155 \\
\hline \multirow{2}{*}{ Other operating revenues/ Total revenues } & IA & 0.191 & 0.193 & 0.219 & 0.177 & 0.167 & 0.142 & 0.180 \\
\cline { 2 - 8 } & Total & 0.183 & 0.182 & 0.213 & 0.193 & 0.170 & 0.163 & 0.183 \\
\hline \multirow{2}{*}{ Personnel cost / Total cost } & IA & 0.185 & 0.180 & 0.166 & 0.156 & 0.148 & 0.129 & 0.160 \\
\cline { 2 - 8 } & Total & 0.190 & 0.187 & 0.189 & 0.190 & 0.178 & 0.171 & 0.184 \\
\hline
\end{tabular}

Source: Own calculations based on the data company database Albertina.

Table 5: Selected ratio-based indicators in 2007-2012 - small enterprises.

year. Quick ratio is higher in enterprises total. Value added-to-revenues ratio does not differ much and other operational costs/revenues ratio was only slightly higher in the enterprises categorized IA.

Table 5 shows selected indicators of "smalle agricultural enterprises, in accordance with EU classification. In this class, similar trends can be seen, however, their intensity is different. Again, IA enterprises have higher profitability, however, the difference is not too big. ROE value in enterprises total in 2009 (global economic crisis and adverse conditions for agriculture) comes close to threshold value zero. In above-average enterprises, this indicator was lower, still, it remains satisfactory.
Indebtedness is only slightly higher in IA enterprises, remaining almost unchanged within the entire period under consideration. Value added/ Total revenues and Other operating revenues/Total revenues indicators in above-average enterprises and all enterprises do not differ from each other. Small IA enterprises have lower Personnel cost/ Total costs ratio, particularly during global crisis, i.e. starting from 2009.

Similar trends can be seen in medium-sized enterprises (Table 6), yet differing in their levels. Profitability indicators (ROE, ROA) are significantly lower, compared with the preceding classes; on average, they are below 5\%. Dramatic 


\begin{tabular}{|l|c|c|c|c|c|c|c|c|}
\hline Ratio & & $\mathbf{2 0 0 7}$ & $\mathbf{2 0 0 8}$ & $\mathbf{2 0 0 9}$ & $\mathbf{2 0 1 0}$ & $\mathbf{2 0 1 1}$ & $\mathbf{2 0 1 2}$ & Average \\
\hline \multirow{2}{*}{ ROA in \% } & IA & 5.81 & 4.85 & 1.44 & 3.60 & 7.58 & 6.37 & 4.38 \\
\cline { 2 - 9 } & Total & 5.84 & 3.94 & 1.05 & 2.95 & 5.96 & 5.43 & 3.63 \\
\hline \multirow{2}{*}{ ROE in \% } & IA & 7.17 & 5.43 & 0.72 & 4.00 & 9.43 & 7.94 & 4.51 \\
\cline { 2 - 9 } & Total & 7.47 & 4.41 & 0.17 & 2.89 & 6.75 & 6.17 & 2.95 \\
\hline \multirow{2}{*}{ Debt ratio v \% } & IA & 37.74 & 39.84 & 39.31 & 40.98 & 42.53 & 45.48 & 40.91 \\
\cline { 2 - 9 } & Total & 38.06 & 39.15 & 37.43 & 36.78 & 37.06 & 38.03 & 37.74 \\
\hline \multirow{2}{*}{ Quick Asset ratio } & IA & 1.482 & 1.271 & 1.177 & 1.070 & 1.176 & 1.063 & 1.199 \\
\cline { 2 - 9 } & Total & 1.404 & 1.205 & 1.184 & 1.173 & 1.167 & 1.153 & 1.212 \\
\hline \multirow{2}{*}{ Value added/Total revenues } & IA & 0.256 & 0.227 & 0.168 & 0.208 & 0.243 & 0.239 & 0.221 \\
\cline { 2 - 9 } & Total & 0.238 & 0.213 & 0.165 & 0.202 & 0.230 & 0.225 & 0.210 \\
\hline \multirow{2}{*}{ Other operating revenues/ Total revenues } & IA & 0.140 & 0.146 & 0.175 & 0.165 & 0.146 & 0.127 & 0.149 \\
\cline { 2 - 9 } & Total & 0.135 & 0.136 & 0.163 & 0.157 & 0.137 & 0.130 & 0.143 \\
\hline \multirow{2}{*}{ Personnel cost / Total cost } & IA & 0.229 & 0.215 & 0.211 & 0.200 & 0.177 & 0.169 & 0.199 \\
\cline { 2 - 8 } & Total & 0.212 & 0.206 & 0.211 & 0.208 & 0.195 & 0.189 & 0.203 \\
\hline
\end{tabular}

Source: Own calculations based on the data company database Albertina.

Table 6: Selected ratio-based indicators in 2007-2012 - medium enterprises.

decrease of these indicators can be seen in the period of global crisis, i.e. in 2009. The indebtedness fell slightly in IA enterprises, however, the difference is not significant. In other indicators, the differences between above-average and other medium-sized enterprises are negligible. The same trend of ROA was observed by Střeleček, et al. (2012). Brožova and Vaněk (2013) noted similar trend of ROA and ROE but the absolute values of indicators (ROA, ROE) were different (higher values). These differences could be caused by integrate of large enterprises. Development of values ROA has been slightly different in international comparison (EU 27 - FADN EU farm economics data). The growth rate was lower and its size was about two percentage points lower than in the Czech Republic.

\section{Conclusion}

The objective of this article is to provide characteristics of above-average enterprises, considering also their size. Summarising the results of the analysis, it can be said that above-average enterprises, regardless their size, have higher profitability (ROA and ROE), higher debt ratio and slightly lower quick ratio. These facts can be regarded as confirmation of close relationship between indicators of efficiency of labour production factor and those showing financial performance. Labour productivity was very often influenced primarily by reducing the number of workers more than the growth of production (Lososová, Zdeněk, 2014). On the other hand, there are bigger differences between above-average and all enterprises in small enterprise class, compared with other size classes. On average, micro and small enterprises achieve higher profitability than medium-sized enterprises, irrespective of whether they are categorized "above-average" or not. The indebtedness decreases as the size of enterprises diminishes, i.e. the highest indebtedness can be seen in micro enterprises ( $56 \%$ on average), whereas the lowest indebtedness is in medium-sized enterprises (38\% on average); at the same time, the indebtedness was higher in above-average enterprises compared with total quantity of enterprises in all size classes. The highest quick ratio was discovered in medium-sized enterprises (approx. 1.2) throughout the relevant period, compared with 0.93 in micro enterprises. It can be said that aboveaverage enterprises had lower quick ratio than all enterprises in all size classes, i.e. the bigger the enterprise, the higher quick ratio. Value added/ total revenues ratio differs mainly with size, i.e. the bigger enterprise, the higher ratio. The subsidy/revenue ratio, as reflected by other operational revenues/total revenues ratio, also differs with size. Obviously, the highest value of this indicator can be seen in micro enterprises (approx. 22\%), compared with $14 \%$ in medium sized enterprises. This difference is attributable, largely, to patterns of agricultural production. The share of personnel costs in total costs increases with size of the enterprise: micro - approx. 14\%, small - approx. $18 \%$, and medium - approx. 20\%). It can also be said that this value is lower in aboveaverage enterprises (of all size classes), compared with the value applicable to all enterprises in the relevant class. 
Corresponding author:

Ing. Martina Novotná, Ph.D.,

Department of Economics, Faculty of Economics, University of South Bohemia

Studentská 13, 37005 České Budějovice, Czech Republic

Phone: +420607 163 923, E-mail: novnotna@ef.jcu.cz

Corresponding author:

Ing. Tomáš Volek, Ph.D.,

Department of Economics, Faculty of Economics, University of South Bohemia

Studentská 13, 37005 České Budějovice, Czech Republic

Phone: +420 607163 923, E-mail:volek@ef.jcu.cz

\section{References}

[1] Ball, V. E., San-Juan-Mesonada, C., Ulloa, C. A. State productivity growth in agriculture: catchingup and the business cycle. Journal of Productivity Analysis. 2014, Vol. 42, No. 3. p. 327-338. ISSN 0895-562X. doi: 10.1007/s11123-013-0352-0.

[2] Barro, R. J., Sala-i-Martin, X. Economic growth. 2 $2^{\text {nd }}$ ed. Cambridge: MIT Press. 2004. ISBN 0-262-02553-1.

[3] Brčák, J. Labour productivity in Vzech agriculture and factors of its improvement. Scientia Agriculturae Bohemica. 2009, Vol. 40, No. 4, p. 236 - 244. ISSN 1211-3174.

[4] Cuadrado-Roura, J. R., Mancha-Navarro, T., Garrido-Yserte, R. Regional productivity patterns in Europe: An alternative approach. Annals of Regional Science, 2000, Vol. 34, No. 3, p. 365-384. ISSN 0570-1864.

[5] Coelli, T. J., Rao, D. S. P., O'Donnell, C. J., Battese, G. E. An introduction to efficiency and productivity analysis. $2^{\text {nd }}$ ed. New York: Springer. 2005. ISBN 0-387-24266-X.

[6] Brožová, I., Vanek, J. Assessment of economic efficiency of conventional and organic agricultural enterprises in a chosen region. Acta Universitatis Agriculturae et Silviculturae Mendelianae Brunensis, 2013, Vol. 61, No. 2, p. 297-307. ISSN 1211-8516.

[7] Čechura, L. Technical efficiency and total factor productivity in Czech agriculture. Agricultural Economics. 2012 58, No. 4, p. 147-156, ISSN 0139-570X.

[8] European Commission. EU farm economics 2009 - 2012 based on FADN data. 2013, Brussels. [Online] Available: http://ec.europa.eu/agriculture/rica/database/database_en.cfm [Accessed: 15th March 2015].

[9] Kazukauskas, A., Newman, C., Sauer, J. The impact of decoupled subsidies on productivity in agriculture: a cross-country analysis using microdata. Agricultural Economics. 2014, Vol. 45, No. 3, p. 327-336, ISSN 0169-5150 . doi: 10.1111/agec.12068

[10] Lososová, J., Zdeněk, R. Key factors affecting the profitability of farms in the Czech Republic. Agris On-line Papers in Economics and Informatics. 2014, Vol. 6, No. 1, p. 21-36. ISSN 1804-1930.

[11] Mugera, A. W., Langemeier, M. R., Featherstone, A. M. Labor productivity convergence in the Kansas farm sector: a three-stage procedure using data envelopment analysis and semiparametric regression analysis. Journal of Productivity Analysis. 2012, Vol. 38, No 1., p. 63-79. ISSN 0895-562X. doi: 10.1007/s11123-011-0235-1

[12] Oosterhaven, J., Broersma, L.. Sector structure and cluster economies: A decomposition of regional labour productivity. Regional Studies, 2007. Vol. 41, No 5., p. 639-659. ISSN 0034-3404, doi: 10.1080/00343400601120320.

[13] Prescott, E. C., Lawrence R. Klein Lecture 1997: Needed: A Theory of Total Factor Productivity. International Economic Review, 1998, Vol. 39, No. 3, p. 525-551. ISSN 0020-6598, doi: $10.2307 / 2527389$. 
[14] Střeleček, F.,, Kopta, D., Lososová, J., Zdeněk, R. Economic results of agricultural enterprises in 2010. Acta Universitatis Agriculturae et Silviculturae Mendelianae Brunensis, 2012, Vol. 60, No. 7, p. 315-328. ISSN 1211-8516.

[15] Svatoš, M., Smutka, L., Selby, R. Capital stock value development in relation to the new EU countries' agricultural sector development. Acta Universitatis Agriculturae et Silviculturae Mendelianae Brunensis, 2014, Vol. 62, No. 6, p. 1437-1450. ISSN 1211-8516.

[16] Van den Ban, A. Increasing Labour Productivity in Agriculture and its Implications. The Journal of Agricultural Education and Extension, 2011, Vol. 17, No 5., p. 401- 409. ISSN 1389-224X, doi: 10.1080/1389224X.2011.596414.

[17] Žídková, D., Řezbová, H., Rosochatecká, E. Analysis of Development of Investments in the Agricultural Sector of the Czech Republic. Agris on-line Papers in Economics and Informatics, 2011, Vol. 1, No 3., p. 33 - 43. ISSN1804-1930. 